ELORE (ISSN 1456-3010), vol. 20 - 1/2013.

Julkaisija: Suomen Kansantietouden Tutkijain Seura ry.

[http://www.elore.fi/arkisto/1_13/saarinen.pdf]

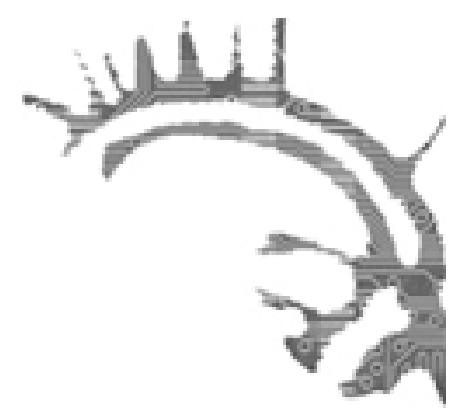

\title{
KIRJA-ARVIO
}

\section{KÖYHÄN KANSAN KERTOMAA}

STARK, EIJA 2011: Köyhyyden perintö. Tutkimuskulttuurisen tiedon sisällöistä ja jatkuvuuksista suomalaissa elämäkerta-ja sananlaskuaineistoissa. Suomalaisen Kirjallisuuden Seuran Toimituksia 1320. Helsinki: SKS. 479 sivua.

\section{Tuija Saarinen}

Suomen väestön valtaosalle maalaiskulttuuri oli niukkuuden kulttuuria aina 1960-luvulle saakka. Agraarinen elämäntapa säilyi vahvana pitkälle 1900-lukua, ja kansantalous kasvoi nopeasti vasta toisen maailmansodan jälkeen. Köyhyys oli historiallinen realiteetti, joka kosketti suurinta osaa suomalaisista. Ei siis ihme, että köyhyys esiintyy teemana folkloren eri muodoissa: saduissa, epiikassa ja muistelukerronnassa. Köyhyys kokemuksena jatkuu kertomuksissa ja muistelupuheissa, vaikka elintaso on noussut, eikä köyhyys enää ole laajojen joukkojen kokemus ja elämäntapa. Suomessa ei kuolla aliravitsemukseen, vaikka puutteesta ja köyhyydestä leipäjonoissa puhutaankin. Olemme siirtyneet absoluuttisesta köyhyydestä suhteelliseen köyhyyteen, jolla laajasti ottaen tarkoitetaan yleistä sosiaalista huono-osaisuutta. Rajanveto köyhyyteen on siten kontekstisidonnainen. Silti hekin, jotka eivät ole kokeneet agraarisuutta ja köyhyyttä, jakavat näitä koskevan kansallisen itseymmärryksen. Köyhyyttä ei siis ole tarvinnut itse kokea, jotta siitä osaisi kertoa ja toistaa sen sisältöä eri perinteenlajeissa.

Eija Starkin väitöskirjan Köyhyyden perintö. Tutkimus kulttuurisen tiedon sisällöistä ja jatkuvuuksista suomalaisiss a elämäkerta- ja sananlaskuaineistoissa teoreettinen näkökulma liittyy kognitiivisen kulttuurintutkimuksen parissa käytyyn keskusteluun ihmisen 
tavasta käsitellä tietoa kognitiivisen järjestelmän puitteissa. Stark lähestyy maalaisköyhyydelle annettuja sisältöjä ja kuvauksia suullisten ja kirjallisten tekstiaineistojen valossa. Hänen tutkimusaineistoinaan ovat etupäässä Kansanrunousarkiston, joissain määrin myös Työväen Arkiston aineistoihin kuuluneet elämäkerrat ja sananlaskut 1800-luvun lopusta 1900-luvun lopulle asti. Sananlaskut ovat kansanomaista puhekieltä arkisessa elämänkulussa ja kytkeytyvät sosiaalisen vuorovaikutuksen tilanteisiin. Ne sisältävät käyttäytymisnormeja, ohjeita, käskyjä ja kieltoja. Elämäkerrallinen aineisto puolestaan jakautuu omaelämäkertoihin ja teksteihin, joissa kuvauksen kohteena on jonkin toisen kuin kirjoittajan elämä. Tutkimuksen keskeisinä kysymyksinä ovat: mihin asioihin ja ilmiöihin köyhyys on puheen tasolla liitetty ja minkälaisia vaikutuksia köyhyydellä on ajateltu olevan ihmisten välisiin suhteisiin? Tutkimuksen perustana on näkemys, että puhe ja kerronta ovat käyttäjilleen merkityksellistä toimintaa. Kertoessaan köyhyydestä ihmiset välittävät eteenpäin käsityksiään todellisuudesta ja siihen liittyvistä normeista.

\section{KULTTUURINEN TIETO JA KÖYHYYSPUHE}

Teoksen metodologisena lähtökohtana on ajatus, että toisistaan riippumattomien kertojien ilmaisemat sanansisältöiset mielikuvat, käsitykset ja uskomukset viittaavat jaettuun kulttuuriseen tietoon. Stark nimittää elämäkerrallisen aineiston ja sananlaskujen köyhyyttä koskevaa kerrontaa köyhyyspuheeksi. Köyhyyspuhe on rajattu löyhästi käsittämään kaikenlaisten köyhyysaiheisten ajatusten ilmaisemista niin puhuttuna kuin kirjoitettuna kielenä. Lajikriteerinä on siis kertomuksen tai sananlaskun sisältö.

Köyhyyspuhetta voi nimittää myös köyhyysdiskurssiksi tai -diskursseiksi. Stark käsittää diskurssien kuuluvan tiedon ja sen koostamisen alueelle kriittisen diskurssianalyysin tapaan. Puhe köyhyydestä ei ole sama asia kuin köyhyys historiallisena kokemuksena tai ilmiönä. Elämäkerroissa ja sananlaskuissa olevan köyhyyspuheen prosessointipaikka on ihmismieli. Tutkimalla puhetta köyhyydestä astutaan toiveiden, pelkojen, ennakkoluulojen, idealisaatioiden, uskomusten ja muun inhimillisen ajattelun tutkimisen pariin. Köyhyys muodostuu siten todellisuudesta kertovista esityksistä, representaatioista, jolla tarkoitetaan asian esittämistä uudessa muodossa. Teemat ovat tutkijalle kulttuurisen tiedon representaatioita kollektiivisen toiston ja muuntelun prosesseissa, eikä kerrottujen tapahtumien todellisuutta voi yksiselitteisesti johtaa tapahtuneista asioista.

Sananlaskut ja elämäkerrat sisältävät köyhyyspuhetta, jossa on kyse yksilön elämästä ja siihen sisältyneistä kokemuksista. Silti yhteisön traditio, sosiaaliset konventiot ja historialliset olot ovat muovanneet kokemuksia ja niiden ilmaisemista samantapaisiksi. Starkin mukaan köyhyydestä puhuvat he, joille sillä on omakohtaista merkitystä niin paljon, että sitä halutaan reflektoida. Toki köyhyydestä saattavat puhua myös he, jotka eivät ole sitä kokeneet. Köyhyys yhteiskunnassa havaittavana ilmiönä sekä henkilökohtaisena kokemuksena tehdään merkitykselliseksi verbaalisen prosessin aikana. Köyhyyspuheesta tulee osin perinnettä sen vuoksi, että sitä on mahdollista toistaa, muunnella ja ylläpitää kirjoitustaidon avulla. Sitä välitetään eri muodoissa myös kaunokirjallisuuden ja vaikkapa iskelmien sanoituksissa: "[..] on täällä elämä raskasta työtä, ja siinä harvemmin on onni myötä, sen tietää vain yksin suomalainen." 
Köyhyyspuheeseen liittyy kollektiivisia ulottuvuuksia, sillä puheen sisällöt liittyvät käsityksiin suomalaisuudesta. Starkin mukaan köyhyyden olemassaolo kokemuksena ja mielikuvana on heijastunut tapoihimme havainnoida maailmaa, eikä tavasta irrottauduta hetkessä. Ylisukupolviset ajattelumuodot on sisäistetty, ja niitä opetetaan myös uusille sukupolville. Siten ne velvoittavat traditionmukaiseen käytökseen. Köyhyyden henkilökohtaiset kokemukset ja mielikuvat köyhyydestä yhtyvät yhtenäiseksi köyhyyspuheeksi. Ne sisältyvät suomalaiskansalliseen ideologiapuheeseen samoin kuin esimerkiksi puhe molempien sukupuolten tekemästä ankarasta työstä tai naisista yhteiskunnan tukipilareina. Köyhyyspuheessa ilmaistaan kollektiivisia, monien jakamia ajattelumalleja kaavoittuneiden käsitysten ja tietynlaisten perusmetaforien kautta. Teoksessa olisi voinut pohtia perusteellisemmin uskonnon vaikutusta - esimerkiksi säästäväisyyden hyvettä ja luterilaista työmoraalia.

Kulttuurisella tiedolla Stark tarkoittaa puolestaan kollektiivisia, ihmisten jakamia yhteneväisiä käsityksiä köyhyydestä. Tekijä on tekstianalyysin avulla määritellyt, mihin osa-alueisiin köyhyyspuhe jakautuu. Sisällön analyysi on tehty kirjaamalla testeissä toistuvia aiheita. Stark on myös verrannut niitä keskenään teemojen määrittelemiseksi. Erityisteemoja analysoitaessa on huomioitu kaikki aihepiiriin liittyvät maininnat. Siten oli mahdollista löytää toistuvia ja konkreettisia köyhyyspuheen tiivistymiä, sisältöaineksia, aihelmia ja kontekstitilanteita. Toistuvia elämäkerrallisia teemoja ovat muun muassa nälän kokeminen, vaatteiden puuttuminen, kerjuulla käynti, koulukiusaaminen huonon ulkonäön vuoksi, perheen sisäinen hierarkia ja työnjako. Sanalaskuissa puolestaan puhuttiin esimerkiksi työstä, laiskuudesta ja ahkeruudesta. Teosta rytmittävät aineistoista poimitut, kevyesti stilisoidut sitaatit.

Köyhyys on monin puolin myös visuaalista. Stark osoittaa, että kysymys oli visuaalisuuden kulttuurista, jossa ihmisestä tehtiin hänen ulkonäkönsä ja käytöksensä perusteella sangen syvälle meneviä arvioita. Hyväosaiset tunnisti ulkonäöstä ja herra erottui köyhästä. Myös toimintatavat erottuivat. Havainto on ajankohtainen edelleenkin nykyisin, jolloin vaikkapa merkkilaukut toimivat statuksen osoittajina ja erottajina vähemmän menestyneistä. Lukijana olisin silti kaivannut myös esimerkkejä visuaalisista aineistoista, jotka olisivat tarjonneet herkullisen lisäulottuvuuden. Yksi mielenkiintoinen jatkotutkimuksen mahdollisuus tarjoutuukin köyhyyden visuaalisen representaation tarkastelemiseen.

\section{NYKYPÄIVÄÄN ULOTTUVAT YHTEYDET}

Starkin tutkimuksen merkittävimpänä antina on osoittaa, kuinka olennainen osa köyhyydellä on kulttuurissamme. Isovanhemmilta peritty tapa havainnoida maailmaa ei katoa. Havainnoimme, puhumme ja toimimme köyhyyden kulttuurista käsin vielä nykysinkin. Monet järjestöt, kuten Martat tai erilaiset yleisöä neuvovat julkaisut alkaen Pirkan rakastetusta niksipalstasta, opettavat senttejä venyttämällä selviytymään mahdollisen vähin investoinnein. Vaikka nykyköyhyys on sisällöltään erilaista kuin 1800-luvun köyhyys, muokkaamme puhettamme ajankohtaamme sopivaksi. Teos onkin siltä osin sangen ajankohtainen, ja sen tulokset sovellettavissa myös tähän päivään: arvotamme 
edelleen köyhyyttä. Kontekstista riippuen joko syyllistämme heikommin yhteiskunnassa menestyneitä välinpitämättömyydestä ja yrittämisen halun puutteesta. Hyväosaisten näemme helposti väheksyvän heikosti menestyneiden tarpeita tai peräti hyötyneen muiden väestönosien kustannuksella. Työttömiä syytetään edelleen tilansa itse aiheuttajiksi ottamatta keskustelussa huomioon ympäröivää yhteiskunnallista todellisuutta. Siirrämme köyhyyden kulttuurista tietoa edelleen.

Filosofian tohtori Tuija Saarinen työskentelee tutkijana Karjalan tutkimuslaitoksella Itä-Suomen yliopistossa dosentti Tuulikki Kurjen johtamassa, Suomen Akatemian projektissa Rajaseudun kirjoituskulttuurit ja traditiot. 